\title{
Teaching Intensive Reading in TESOL Class-A Mosaic Model
}

\author{
Peng Zhao, Xueyan Wu, Mengting Hu, Yiyi Yang \\ Zhongbei College, Nanjing Normal University, Danyang, China \\ Email: promisingscholar@163.com
}

How to cite this paper: Zhao, P., Wu, X. Y., Hu, M. T., \& Yang, Y. Y. (2020). Teaching Intensive Reading in TESOL Class-A Mosaic Model. Open Journal of Modern Linguistics, 10, 340-365.

https://doi.org/10.4236/ojml.2020.104020

Received: July 28, 2020

Accepted: August 22, 2020

Published: August 25, 2020

Copyright $\odot 2020$ by author(s) and Scientific Research Publishing Inc. This work is licensed under the Creative Commons Attribution International License (CC BY 4.0).

http://creativecommons.org/licenses/by/4.0/

\begin{abstract}
The paper intends to demonstrate a Mosaic model in teaching intensive reading in TESOL class on the basis of constructivist theory of learning and teaching. Mosaic is an abbreviation for the following teaching procedure: making use of academic content, organizing information, scaffolding instruction, activating prior knowledge, interacting with others, cultivating critical thinking. The paper attempts to apply the Mosaic model to the intensive reading of Katherine Mansfield's $A$ Dill Pickle at three levels: literal, critical and affective.
\end{abstract}

\section{Keywords}

MOSAIC, POA, Scaffolding, Interaction, Critical Thinking, Character Building

\section{Introduction}

\subsection{Constructivist Theory of Learning and Teaching}

\subsubsection{View on Knowledge}

First of all, knowledge is not the absolute and objective reflection of the reality, rather than a kind of interpretation and hypothesis of reality. Therefore, knowledge can neither serve as key to solving all problems, nor define the universal principles. People have to reconstruct and recreate knowledge according to specific problem. Then, it is the conviction of the constructivists that knowledge takes on importance only if it is integrated into the knowledge system of human beings. On this theoretical basis, constructivists advocate that the learning of new knowledge of the Ss should be regarded as reconstruction and recreation of acquired knowledge; teachers should lead the Ss to build up knowledge under 
their own experience backgrounds instead of instructing them in predetermined materials.

\subsubsection{View on Learning}

The constructivism has transformed our concept of education from "knowledge is a product" to "learning is a process" (Jones \& Brader-Araje, 2002: p. 89), so the assessment of learning should be divided into formative and summative assessments. Constructivist emphasizes that "learners should participate actively into meaningful experiencing activities in complete and real environment" (Piaget, 1967: p. 145). The acquiring of knowledge is the cognitive process of reconstructing and recoding of the newly acquired knowledge and of integrating and assimilating it into one's own knowledge system. Learning is characterized by the interplay between learner and the learning environment.

\subsubsection{View on Teaching}

Constructivist teaching initiates the concept that "Ss being the center and teacher being the guide", which has subverted the traditional teaching concept. The notion can be interpreted from two perspectives: 1) The teacher as a guide and cooperator instead of traditional authority, is to work with the student to build favorable learning environment and lead the Ss to conduct independent research and cooperative learning through discussion and communication. 2) The teaching should be student-oriented which means the Ss is the master of the class and the constructor of meanings while the teacher being the partner who accelerates the construction of meaning. The Ss are given more initiative and are supposed to undertake more independent learning.

\subsection{The Concept of the Teaching Plan: MOSAIC}

MOSAIC intensive reading has been designed by the application of constructivist theory of learning and teaching to make teaching more effective and interpretation more insightful. The structure of the teaching plan is influenced by Adams W. Royce who in his book Developing Reading Versatility classifies reading into three levels: "literal reading, critical reading and affective reading" (Royce, 1989: p. 185). The interpretation of the short story focuses on the affective level. According to Rosenblatt's reader response theory, the affective level in reading stresses the cognitive and emotional experience of individual reader in the whole reading process.

\section{MOSAIC model:}

\section{1) Making use of academic content}

Materials and task based on academic content and experiences give learning real purpose. Students explore real world issues, discuss academic topics, and study content-based and thematic materials.

\section{2) Organizing information}

Students learn to organize thoughts and notes through a variety of graphic organizers that accommodate diverse learning and thinking styles. 


\section{3) Scaffolding instruction}

A scaffold is a physical structure that facilitates construction of a building. Similarly, scaffolding instruction is a tool used to facilitate language learning in the form of predictable and flexible tasks. Some examples include oral or written modeling by the teacher or students, placing information in a larger framework, and reinterpretation.

\section{4) Activating prior knowledge}

Students can better understand new spoken or written material when they connect to the content. Activating prior knowledge allows students to tap into what they already know, building on this knowledge, and stirring a curiosity for more knowledge.

\section{5) Interacting with others}

Activities that promote human interaction in pair work, small group work, and whole class activities present opportunities for real world contact and real world use of language.

\section{6) Cultivating critical thinking}

Strategies for critical thinking are taught explicitly. Students learn tools that promote critical thinking skills crucial to success in the academic world.

\section{Lead-In}

The lead-in part consists of three steps. According to production-oriented approach (hereafter referred to as POA), the teacher will optimize the traditional teaching procedures, changing them into a series of circular chains consisting of motivating, enabling and assessing. "The main task of motivating is to make students realize their shortcomings through output, thereby mobilizing their enthusiasm for learning and stimulate their desire to learn" (Wen, 2018: p. 396). At the very beginning, therefore, the teacher will give an explanation of the title in the first step to motivate students' interest, illustrating the shape, color, function and taste of "Dill Pickle". Then, we enter into enabling procedure in which "scaffolding instruction is adopted to arouse interest and facilitate learning in the form of predictable and flexible tasks" (Wen, 2015: p. 547). The teacher will arrange this procedure through three love-related warm-up questions, organizing students to have an exchange of discussions. In this part, teachers should take students' actual knowledge level and ability level as an important reference point when designing teaching activities. Three love-related questions are well-designed in this part, presenting three major features. First, each question is illustrated with food-related paintings to stimulate students' learning interest. Second, the teacher will be prepared for the words and sentence patterns that students may use to answer these questions, which helps students to obtain and organize information with target language, and enhances students' sense of self-confidence and effectiveness. Third, for the sake of enlightening the minds of students, the arrangement of three questions follows the principle of gradual improvement, from simple to complex, from easy to difficult, and from rough to thorough, in- 
cluding "What is the taste of love?", "Can love taste like a dill pickle?" and "Why does the author use 'a dill pickle' as the title of this short story?" Specifically, the third warm-up question is in the form of predictable task, concerned with the implication of the title as well as the interpretation of the theme. Students are encouraged to think and analyze this question from different perspectives. After answering these three questions, students will find it easier to make an exploration of the profound connotations of the theme. After that, a brief introduction to the author-Katherine Mansfield will be demonstrated to the students. In this step, students will be asked to listen to a recording of the author's life story and fill in missing words. By engaging in this listening activity, not only can students have a brief understanding of the author, but also can students improve their listening ability.

\section{Outline}

2.1. A brief introduction of the title

2.2. Warm-up questions

2.3. A brief introduction to the author

Teaching objective: guide students to analyze the literal meaning as well as the connotative meaning, and pave the way for the teaching of the text.

Character building aim: in this part, the teacher will encourage students to compare different tastes of love through preset questions related to love, guide students to think about the meaning and significance of love, and give students proper guidance concerning which kind of love is instructive, inspiring and helpful.

Teaching strategy: interactive teaching method, permeation of humanism, heuristic method of teaching comparative study of oriental and occidental cultures, intercultural communication practice and cultivation of critical thinking.

Key point: encourage students to share their understanding of love.

Difficult point: guide students to analyze and grasp the multi-dimensional meanings of the title.

\subsection{A Brief Introduction of the Title}

\section{Activating prior knowledge}

What is a dill pickle?

Dill: $n$. an aromatic herb native to Eurasia with finely dissected leaves and small yellow flowers clustered in umbels. The leaves or seeds of this plant is used as a seasoning.

Pickle: an edible product, such as a cucumber, that has been preserved and flavored in a solution of brine or vinegar.

In western countries, it is eaten with hamburger as an appetizer. It tastes very sour, spicy, bitter and sweet.

\subsection{Warm-Up Questions (Provided with Food-Related Paintings)}

Scaffolding instruction: Words and sentence patterns provided 
Words Bank: sour, sweet, bitter, romantic, mesmerizing, reciprocal, unrequited, heart-broken...

Sentence Patterns: It seems to me that.../It is my conviction that.../As an individual level, I feel that...etc.)

1) What is the taste of love?

Answer: chili, ice-cream, chocolate, water, poison...

2) Can love taste like a dill pickle?

3) Why does the author use "a dill pickle" as the title of this short story? Answer:

a) From the hero's point of view: The hero considers Vera just an appetizer, not a main course. That is to say, Vera is not an ideal girl that the man would like to spend the whole life with. She only makes his dull life a little colorful.

b) From the heroine's perspective: The title reveals the current status of the heroine-not as healthy and fresh as before, filled with bitter and sour taste.

c) On the whole: The title is a symbol of the hero and the heroine's relationship. Their love, just like a dill pickle, has changed a lot and went through sweetness, sourness, and bitterness.

\subsection{A Brief Introduction to the Author-Listen and Fill in the Missing Words (Provided with Recording)}

Katherine Mansfield (1888-1923), British short-story writer, was born in Wellington, New Zealand. She is considered one of the greatest masters of the short-story form. At the age of 18 she settled in London to study music and to

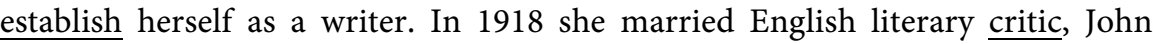
Middleton Murry.

Mansfield's middle class background provided the setting for many of her stories and mortality-perhaps due to her illness-dominated her writing. Her creative years were burdened with loneliness, illness, jealousy and alienation-all reflected from her work in the bitter depiction of marital and family relationships of her middle-class characters.

As a New Zealand's most famous writer, she was closely associated with D.H. Lawrence and something of a rival of Virginia Woolf. Her short stories are also notable for their use of stream of consciousness. Much influenced by Russian writer Anton Chekhov, Mansfield depicted trivial events and subtle changes in human behavior.

\section{Literal Reading}

Intensive reading at literal level adheres to the mixed teaching mode. The students are allowed to take online courses to learn superficial knowledge, leaving more class time for targeted problems, questioning, discussion, and other productive activities. In the process, situational language teaching is applied to helping the students memorize the words and phrases vividly and select them correctly according to the specific context. And exercise in class aims to conso- 
lidate the key points for deep learning. Moreover, heuristic method of teaching is used in grammar part to encourage the students to grasp the knowledge actively and express proficiently in different occasions for effective communication.

\section{Outline}

\subsection{Key Words and Phrases}

3.1.1. Warm-up for words (motivating)

3.1.2. Situational language teaching (enabling)

3.1.3. Consolidation (assessing)

\subsection{Sentence Structures and Grammar}

3.2.1. Warm-up for sentence (motivating)

3.2.2. Heuristic method of teaching (enabling)

3.2.3. Conclusion (assessing)

"POA: production-oriented approach" (Wen, 2015: p. 547)

\section{Teaching objective:}

Be able to master the meaning and usage of words and phrases, understand the structure of sentences, and use them proficiently in different situations for effective communication and expression.

Character building aim:

1) Empower the students to discuss the theme of this lesson with new words and phrases.

2) Rethink the outlook on life and values in line with the comprehension of the text and their emotional experiences.

\section{Key point:}

Grasp the usage and collocation of target words in TEM4.

Difficult point:

Apply the target words and sentence structures flexibly to the appropriate context.

\subsection{Key Words and Phrases}

\subsubsection{Warm-Up for Words}

\section{Making use of academic content:}

1) Preview the new words and phrases in the text; listen to the recording and then repeat.

2) Give the students some key words and phrases; guide them to read the text quickly and find out the sentences which contain the language points.

Teaching strategy: Materials and task based on academic content give learning real purpose. The way of listening and exploring is more likely to make students familiar with the spelling and pronunciation.

\subsubsection{Situational Language Teaching}

\section{Organizing information:}

List the corresponding sentences and let the students paraphrase the expressions in bold type for better comprehension. "Prediction encourages the students 
to use their existing knowledge to facilitate understanding of new ideas encountered in the text" (Lo, Yeh, \& Sung, 2010: pp. 180-189).

Teaching strategy: Create a topic environment, presenting vocabularies, inspire the students to guess the meanings of these words, and then simulate the scenes through relevant example sentences. In this way, the students will better understand new materials when they connect to the content.

I don't know what it is-I've often wondered-that makes your voice such a haunting memory... (Yang, 2011: p. 59)

haunting

adj. Sounds, images or words remain in your thoughts

Each one of these ancient towns is hauntingly beautiful.

Haunt (Hornby, 2004: p. 806)

vt. To regularly appear in the place; to keep thinking or worrying about something.

Any deal based on a lie will come back to haunt you.

Suddenly with a quick gesture he handed her back the glove and scraped his chair on the floor (Yang: 63).

scrape (Hornby, 2004: p. 1556)

vt. pulling a sharp object over the surface; making a noise or causing slight damage

She stumbled and fell, scraping her palms and knees.

scrape by

The true sign of success is not whether we are a source of perpetual aid that helps people scrape by. It's whether we are partners in building the capacity of transformational change.

scrape through

We should work hard so as to avoid scraping through the final exam.

And it is not necessary to know the language-the life of the boat creates a bond between you and the people that's more than sufficient (Yang: 61).

Sufficient (Hornby, 2004: p. 1766)

adj. enough to meet a need or purpose; adequate

Only when agriculture is fully developed can industry have sufficient materials and markets.

As in all friendship, a husband and wife must try to interest each other, and to spend sufficient time sharing absorbing activities to give them continuing common interests.

\section{Derived forms}

suffice $\mathrm{v}$.

sufficiently adv.

sufficiency $\mathrm{n}$.

But she was thinking how well she remembered that trick of his-the trick of interrupting her-and of how it used to exasperate her six years ago (Yang: 59).

exasperate (Hornby, 2004: p. 588) 
vt. 1) to cause great irritation or anger to; infuriate;

2) to cause an unpleasant feeling or condition; to worsen.

The furious behavior of an angry man is more likely to exasperate us against himself than against his enemies.

The important thing is that you do not panic, as this will only exasperate the negative experience.

Derived forms

exasperatedly adv.

exasperating adj.

exasperatingly adv.

exasperation $\mathrm{n}$.

As he spoke, so lightly, tapping the end of his cigarette against the ash-tray, she felt the strange beast that had slumbered so long within her bosom stir, stretch itself, yawn, prick up its ears, and suddenly bound to its feet, and fix its longing, hungry stare upon those far away places (Yang: 60).

Stretch (Hornby, 2004: p. 1746)

vt. 1) to lengthen, widen

2) to spread out fully; extend from one place to another or across a given space or time

The procession stretches for miles.

His memory stretches back to his hardworking age.

stretch one's legs

I've been sitting here for three hours, I really need to stretch my legs.

stretch the truth

We should not stretch the truth about how much we have helped the project.

He laid down the orange and pushed back his chair, and she took her little warm hand out of her muff and gave it to him (Yang: 58).

lay down (Hornby, 2004: p. 989)

to put it down; to sacrifice or give up

The drug-traffickers have offered to lay down their arms.

Doctors laid down their own well-being for the good of patients.

\section{Review}

lie lay lain lying

lay laid laid laying

lie lied lied lying

He caught up one of her gloves from the table and clutched at it as if that would hold her (Yang: 62).

clutch at (Hornby, 2004: p. 305)

to hold it tightly

Many desperate couples clutch at straws, seeking medical treatments.

She would clutch at any chance to be exposed to great minds.

In the warmth, as it were, another memory unfolded (Yang: 59).

as it were (Hornby, 2004: p. 81) 
to make what you are saying sound less definite

All departments are, as it were, created equal.

I understood the words, but I didn't, as it were, understand the question.

Now he had the air of a man who has found his place in life (Yang: 60).

have an air of (Hornby, 2004: p. 37)

to look like

I find young people exciting. They have an air of freedom.

If you want to have an air of nobility, you should cleanse your own heart.

He sat there, thunder-struck, astounded beyondwords... (Yang: 63)

beyond words (Hornby, 2004: p. 146)

speechless; at a loss for words;

When he heard the news, he was infuriated beyond words.

$\mathrm{He}$ is not sure what drives his emotion beyond his willingness to help others.

Anything beyond what we need is poison, such as power, ego, loneliness or whatever.

\subsubsection{Consolidation}

\section{Scaffolding instruction:}

Practice by multiple choice.

Teaching strategy: "Scaffolding instruction is the role of teachers and others in supporting the students' development and providing supporting structures to get to the next stage or level” (Lo, Yeh, \& Sung, 2010: pp. 180-189). The goal is to help the students complete tasks independently and facilitate construction of the knowledge in an attempt to placing information in a larger framework

Key: 1) C, 2) D, 3) A

1) Having finished their morning work, the clerks stood up behind their desks, themselves.
A. expanding
B. prolonging
C. stretching
D. extending

2) It's up to each of us to have interest and foresight to learn about the recycling methods in our communities and then to follow those procedures.
A. efficient
B. proficient
C. deficient
D. sufficient

3) The mayor of London, facing tough questions from reporters in recent days regarding rising knife crime plaguing his city, appeared to be during a television interview.
A. exasperated
B. extravagant
C. exaggerated
D. exhilarated

\subsection{Sentence Structures and Grammar}

\subsubsection{Warm-Up for Sentence}

Activating prior knowledge:

1) Brief review of subjunctive mood and participle.

2) Encourage the students to carefully read the target sentences listed out and probe into the pattern after discussion. The teacher can provide some hints if 
necessary.

3) Inspire the students to draw a conclusion about the grammatical structures related to what they are going to learn.

Teaching strategy: Activating prior knowledge in class makes it easier for the students to tap into what they have already known, build on this knowledge, and stir a curiosity for more.

I wish I had taken poison... (Yang, 2011: p. 59)

Subjunctive mood/communicative function: "If you wish something were true, you would like it to be true, even though you know that it is impossible or unlikely.

All of the following are concepts I wish I had known before heading to college.

There are only a few things that truly count for a happy life. I wish I had known to concentrate on those and ignore the rest" (Murphy, 2019: p. 80).

...his face lit up as though he had struck a match in a dark room (Yang, 2011: p. 58).

Subjunctive mood/communicative function: "You use as if and as though when you are giving a possible explanation for something or saying that something appears to be the case when it is not" (Murphy, 2019: p. 80).

e.g. When he found a particularly strong rice plant he was very happy as though he had discovered a gold mine.

I remember the details about the incident as though it was yesterday.

I don't know what it is-I've often wondered-that makes your voice such a haunting memory... (Ibid: 59)

Communicative function: This is an emphatic sentence. "What" is the object of "know" and "is". "That" introduces a relative clause, referring to "what" and serving as the subject of the subordinate clause. It is used to strengthen the tone and attract the attention of listeners.

e.g. He doesn't understand what it is that makes his grandson so crazy about microblogging.

They are trying to figure out what it was that turned one of the twin brothers into a criminal, the other an excellent policeman.

A great many people taking tea in a Chinese pagoda, and he behaving like a maniac about the wasps-waving them away, flapping at them with his straw hat, serious and infuriated out of all proportion to the occasion (Ibid: 59).

There is no predicate verb in the sentence. It consists of two absolute constructions and two present participle phrases and one adjective phrase.

Absolute construction 1: a great many people taking tea in a Chinese pagoda

Absolute construction 2: he behaving like a maniac about the wasps

Participle phrase 1: waving them away

Participle phrase 2: flapping at them with his straw hat

Adjective phrase: serious and infuriated out of all proportion to the occasion Spring having come, we may perhaps look forward to the revival of plants.

The food being cooked, the boy was doing housework. 
It simply was that we were such egoists, so self-engrossed, so wrapped up in ourselves that we hadn't a corner in our hearts for anybody else (Ibid: 63).

The basic sentence structure is subject + link verb + predicative

Subject: it.

Link verb: was.

Predicative: that we were such egoists, so self-engrossed, so wrapped up in ourselves that we hadn't a corner in our hearts for anybody else.

\section{In the predicative clause:}

Main clause: we were such egoists, so self-engrossed, so wrapped up in ourselves.

Subordinate clause: that we hadn't a corner in our hearts for anybody else (Yang, 2011: p. 62).

\subsubsection{Heuristic Method of Teaching Interacting with others:}

Give the students some pictures to make sentences or dialogues in several minutes by using the new grammatical structure, which can check whether they have understood it immediately.

Teaching strategy: Simplify the task to make it more acceptable. Activities promote human interaction in pair work or small group work, presenting opportunities for showing personalities in communication. During the process, the students' interests will be rekindled which can enhance their confidence in learning difficult language points. It would be better to maintain the students' dominant position so as to develop the inductive ability and the innovative consciousness.

\subsubsection{Conclusion}

\section{Cultivating critical thinking:}

The teacher sums up the key points together with the students to review what they have learned and form the framework, which prompt reflection and strengthen the ability of solving the problems.

Teaching strategy: Summarize the knowledge by arranging tasks with an emphasis on the main points, for the purpose of cultivating the subjective initiative and critical thinking.

\section{Critical Reading}

Critical level of comprehension requires students to combine established knowledge and newly learned content aiming to cultivate critical thinking ability. To achieve this goal, the class is composed of five parts based on the students' linguistic competence and textual properties: introducing author's attitude and tone, analyzing the text organization and protagonists, and composing critical thinking questions. This part mainly demonstrates how to apply the theory of constrcutivism to teaching-learning process.

\section{Outline}


4.1. Warm-up (motivating)

4.2. Author's attitude and tone (motivating)

4.3. Text organization and character analysis (enabling)

4.3.1. Worksheets design

4.3.2. "STEAL" approach

4.4. Critical thinking questions (accessing)

"POA: production-oriented approach" (Wen, 2015: p. 547)

Teaching objective: To help students to master the ability to analyze short stories independently by analyzing the author's narrative techniques, coherence features, and figures characteristics.

Character building aim: To cultivate students critical thinking ability and instruct them to form the right view of love and life.

Key points: Focus on the characteristics of short stories and emphasize the character analysis of "STEAL" approach.

Difficult points: Take the details which are easy to be ignored into account and analyze them from multiple angles.

\subsection{Warm-Up}

The class begins with a lecture on Katherine Mansfield's art of writing short stories. Mansfield's fiction is usually set against the "plotted story", and belongs to the "slice-of-life" Chekhovian tradition (Kimber, 2015: p. 6). A Dill Pickle is written in the modernist mode which contains Mansfield's thoughts and reactions, but other than that it resembles a genuine conversation with realistic shifts in topics. She took a glimpse into the reunion of former lovers. For each character, she develops a distinctive voice and an appropriate narrative strategy.

\subsection{Author's Attitude and Tone}

By providing the necessary background knowledge, learners should be capable of comparing the previous learned plotted short stories with Mansfield's.

\section{Interacting with others}

To help students fully understand the Mansfield's art of being brief and the mastery skill of presenting the slice-of-life like a painting, the teacher will organize a discussion on the rhetorical questions, the repetition, the unfinished sentence, and the difference in male and female speech presented in the text. The discussion procedure involves students seated in a circle, motivating and controlling their own discussion, which follows the Harkness discussion method. Students are divided into groups and assigned to read the text and share their opinions and insights about the narrator's unique writing approach with their peers. Everyone participates but not in a competing way. The underlying assumption for this seems to be that it is important to make room for the authentic voice of the student, to provide encouragement, build confidence, and to embed positive attitudes to learning (Williams, 2014: p. 61). The discussion allows teacher 
to observe and differentiate students' understanding level, and the teacher can make a summary based on students' shared reports as well as encourage them by positive responses.

\subsection{Text Organization}

\subsubsection{Worksheets Design}

This part is mirroring the Mosaic teaching concept, which involves organizing the text content and designing in-class tasks with provided scaffolding instruction. Two worksheets are devised specifically for a student-centered learning approach. The topic-based worksheets have the function of concentrating students' attention on analyzing the text structure and allowing students to complete the task within a fairly short space of time by following the instructions. Table 1: Text Organization shows a universal pattern to analyze short stories, which enables students to activate prior analysis skills and adopt it to the new tasks. The worksheet 2, on the other hand, introduces a novel character analysis approach called STEAL.

Table 1. Text organization.

\begin{tabular}{|c|c|c|}
\hline \multicolumn{3}{|c|}{ Text Organization } \\
\hline $\begin{array}{l}\text { Part I: The early } \\
\text { equilibrium }\end{array}$ & Paras. $1-12$ & $\begin{array}{l}\text { A couple of former lovers met by chance in a café } \\
\text { six years after they departed. The man failed to } \\
\text { recognize Vera at first sight. } \\
\text { 1) Characters and settings are introduced to the } \\
\text { audience in this part. } \\
\text { 2) The author reveals the relationship between the } \\
\text { man and woman are prospective lovers instead } \\
\text { of saying it straightforwardly. }\end{array}$ \\
\hline $\begin{array}{l}\text { Part II: The rising } \\
\text { actions }\end{array}$ & Paras. $13-51$ & $\begin{array}{l}\text { Paras. } 13 \text { - 21: They recalled the feelings of the first } \\
\text { afternoon they had spent together at Kew Garden. } \\
\text { (haunting memory vs. absurd scene) } \\
\text { Paras. } 22 \text { - 44: The man was showing off the travelling } \\
\text { experiences, especially the ones in Russia, without } \\
\text { noticing the women's feelings and paying no } \\
\text { attention to Vera's wretched condition. } \\
\text { Paras. } 45 \text { - 51: They recalled the man's boyhood } \\
\text { story together, but Vera remembered some details } \\
\text { clearer than the man himself. }\end{array}$ \\
\hline
\end{tabular}

The man considered the letter Vera once wrote to him was funny to read again. After being Part III: The climax Paras. 52-64 hurt by the man's insensitivity, Vera got some comfort when he pleaded her to stay. Her hope for renewing the relationship aroused until the man's egoism hurt her again.

\begin{tabular}{|c|c|c|}
\hline $\begin{array}{l}\text { Part IV: The final } \\
\quad \text { resolution }\end{array}$ & Paras. 65 - 66 & $\begin{array}{l}\text { Vera made up her mind to leave } \\
\text { the man again bravely. }\end{array}$ \\
\hline
\end{tabular}




\subsection{2. "STEAL" Approach}

When analyzing characters, it is essential to evaluate the five elements mentioned in STEAL approach: speech, thoughts, effect, action, and looks. Character analysis not only captures the subtle hints the author uses to shape the character, but also reads between the lines in the text, paying attention to the details that seem insignificant at first. This process requires students to complete the worksheets of Table 2: STEAL Approach individually with an expectation that they will conduct a certain degree of investigation of the text. The suggested answers are provided as the following:

\section{Scaffolding instruction:}

When finished filling in the worksheets, the teacher should collect answers from students, acknowledge their hard-working, and then point out what they are missing. Further knowledge, like Mansfield wrote from an unique female perspective reflected on the Vera's speech sharply criticized the society of male chauvinism, can be provided after the worksheet task to enhance students' learning on the same topic.

Table 2. STEAL approach.

\begin{tabular}{|c|c|c|}
\hline STEAL Approach & & Characters \\
\hline Speech & Vera & The Man \\
\hline $\begin{array}{l}\text { What important thing } \\
\text { does the character say } \\
\text { that make you } \\
\text { understand what } \\
\text { he/she is like? }\end{array}$ & $\begin{array}{l}\text { Selected examples: } \\
\text { "Sold. Ages ago." (P37) } \\
\text { "How I envy you." (P31 L4) } \\
\text { "Yes, I know perfectly what } \\
\text { you mean." (P44) } \\
\text { "Not a bit," (P56 L1) }\end{array}$ & $\begin{array}{l}\text { Selected examples: } \\
\text { "I get them made for me...ah, } \\
\text { when I was in Russia..." (P25) } \\
\text { He let it go at that. "That river life," } \\
\text { he went on, "is something quite } \\
\text { special..." (P40) }\end{array}$ \\
\hline
\end{tabular}

The first remark, Vera was telling the truth. She is brave as well as realistic, because she sold the piano, gave up on things she was so fond of, for a living. The following three remarks of Vera were lies or only part of truth. She was unwilling to admit her uncertainty about the dill pickle and refused to show her both affection and broken heart

Analysis in front of the man. She is capable of mange her sentimental feelings. Pulling out the Russian cigarette seemed like a good reason for the man to show off the travelling experience. He did it deliberately since he confessed smoking wasn't a habit with him. His speech was boastful and his mind was so focused on himself. The male chauvinist attitude of the man was demonstrated in lines.

\begin{tabular}{ll}
\hline Thoughts & Vera \\
\hline
\end{tabular}

What are his/her thoughts?

Was there just a hint of mockery in his voice? (P46)

Vera was not sure whether the man was seriously showing his
appreciation or mocking at her interest in what he was saying.
Vera was very sensitive.
The man, as an egoist, never hide his thoughts, he expressed
directly without considering other's feeling.


Continued

\begin{tabular}{|c|c|c|}
\hline Effect & & The Man \\
\hline $\begin{array}{l}\text { What is revealed } \\
\text { through his/her effect } \\
\text { on other characters? }\end{array}$ & \multicolumn{2}{|c|}{$\begin{array}{l}\text {...tapped on the table for waitress. (P9 L1) } \\
\text { "Please do not charge me for it." (P66) }\end{array}$} \\
\hline Analysis & \multicolumn{2}{|c|}{$\begin{array}{l}\text { The only third party in this short story is the waitress. } \\
\text { Tapping on the table is not an appropriate way to get your waitress's } \\
\text { attention. Asking not charging for untouched cream is unreasonable in } \\
\text { the restaurant. The man was doing things in his own favour. } \\
\text { The way he treated the waitress indicates he was either lack of } \\
\text { dining etiquette or in disregard of service staff. }\end{array}$} \\
\hline Action & Vera & The Man \\
\hline $\begin{array}{l}\text { What does he/she do } \\
\text { that shows the kind of } \\
\text { person that he/she is? }\end{array}$ & $\begin{array}{l}\text { Six years before: } \\
\text { She leaned over him. (P18) } \\
\text { In the café: } \\
\text { She smiled. (P2 L2) } \\
\text { She sat down opposite to him. } \\
\text { (P4) } \\
\text { It began to play as she spoke. } \\
\text { (P33) } \\
\text { She had buttoned her collar } \\
\text { again and draw down her veil. } \\
\text { (P53) } \\
\text { She gone. (P65 L1) }\end{array}$ & $\begin{array}{l}\text { Six years before: } \\
\text { Behaving like a maniac about the wasps. } \\
\text { (P14 L3) } \\
\text { In the café: } \\
\text { He frowned. (P2 L2) } \\
\text { He closed his eyes an instant, but } \\
\text { opening them his face lit up... (P2 L2) } \\
\text { He interrupted her. (P9 L1) } \\
\text { He echoed her words, laughing too. } \\
\text { (P13 L1) } \\
\text { He pulled a Russian cigarette case out } \\
\text { of his pocket. (P22 L3) } \\
\text { He gave a strange half laugh and leaned } \\
\text { back in his chair. (P29) } \\
\text { He caught up one of her gloves from } \\
\text { the table and clutched at it as if that } \\
\text { would hold her. (P55 L1) } \\
\text { He sat there, thunder-struck, astounded } \\
\text { beyond words... And then he asked } \\
\text { the waitress for his bill. (P65) }\end{array}$ \\
\hline
\end{tabular}

When they were in relationship, they had a great time together. Although Vera suffered from the man's naïve and immature behaviour, she still willing to lean over him and listen to his childish confession. After six years' separation, Vera became more sophisticated. She smiled at the man when she recognized him, but kept a polite and

Analysis safe social distance when she sat down. She listened to the man's traveling experience carefully, which reveals her yearning for the free life and poetic dwelling. Her resolute is depicted at the end when she left the man again decisively.

From his gestures and little tricks, we can easily deduce the man is lacking respect for women, pretentious, and self-centred. Compare to what he did six years before, he became a worse version of himself.

\begin{tabular}{lll}
\hline \multicolumn{1}{c}{ Looks } & \multicolumn{1}{c}{ Vera } & \multicolumn{1}{c}{ The Man } \\
\hline $\begin{array}{l}\text { What does he/she look } \\
\text { like? }\end{array}$ & $\begin{array}{l}\text { Vera wore a veil and a high } \\
\text { fur collar and looked well } \\
\text { in the man's eyes. }\end{array}$ & $\begin{array}{l}\text { His clothes were admirable. } \\
\text { He had the air of man who } \\
\text { had found his place in life. }\end{array}$ \\
\hline & $\begin{array}{l}\text { The author doesn't provide details on Vera's dressing like there is } \\
\text { nothing worth to write on, but describe the man's attire as admirable. } \\
\text { Since they met by chance, the man would not be able to suit up } \\
\text { himself deliberately for the date, which indicates the man may } \\
\text { achieve higher social status. }\end{array}$ \\
\hline
\end{tabular}




\subsection{Critical Thinking Questions}

The last part involves activate prior learned knowledge and employ them to cultivate critical thinking ability and foster the cultural confidence by appropriate debating on difference between the foreign and domestic perspective of elapsed love.

\section{1) Cultivating critical thinking}

Design thinking has been a subject of teaching, research and real-life application in almost every domain and area of education, research and industrial endeavor for the past many years (Pande \& Vijayakumar Bharathi, 2020: p. 36). Critical thinking is an important learning outcome for higher education, and it is a widely accepted educational goal. Hitchcock stated that its adoption as an educational goal has been recommended on the basis of respect for students' autonomy and preparing students for success in life. "Critical thinkers" have the dispositions and abilities that lead them to think critically when appropriate" (Hitchcock, 2018: p. 1).

\section{2) Interacting with others}

The question-based activity designed for this part is required to be implemented in the form of group discussion. Group discussion plays a vital role in understanding the text and facilitates the interaction among students. Sharing of learning equally benefits all participants as well as builds the unity and togetherness among group members. The quality of cordial, cooperative and polite should be developed during the group discussion process, which leads to a healthy criticism. Questions designed for discussion are listed as the following:

Archetype: Vera is named-the man is not. The man is presented as an archetype. Describe the archetype in your own words (Hint: Students should deduce the man's social background, like status, privileges, and shortcomings).

Desire: Does Vera expect a male partner? Find your evidence from the passage (Hint: Female against the setting of early twentieth century was expected to have a husband. It has been six years since they broke up, Vera remained single...).

Struggle: Briefly explain the "Mind System" of the men when he launched into a lecture on his journey in Russia (Hint: Men who go abroad, return home and talk incessantly about What They Have Learned must have been dime a dozen both back then and nowadays).

Anagnorisis: Provide details to illustrate Vera has learnt that the man's gotten more like his terrible former self (Hint: Anagnorisis means the recognition or discovery by the protagonist of the identity of some character or the nature of his own predicament, which leads to the resolution of the plot. Students should observe and compare the behaviours and remarks of the man to six years before from Vera's standpoint).

\section{Affective Reading}

Intensive reading at affective level attempts to integrate character building into 
inquiring into the meaning of the text and exploration of author's style. Affect reading helps to enhance the Ss understanding of the connotation of love and transmit the correct view on love to the Ss while teaching English Literature. "Vygotsky believed that the internalization of culturally produced sign systems brings about behavioral transformations and forms the bridge between early and later forms of individual development. Thus for Vygotsky, in the tradition of Marx and Engels, the mechanism of individual developmental change is rooted in society and culture" (Vygotsky, 1978: p. 7). The instruction of this part focuses on deepening the Ss perception of the eternal theme of love, by literary interpretation, the nourishing and edification of literature. The scaffolding and immersion approaches are to be applied in the task-based thematic instruction to ensure the integration of language teaching and character building.

\section{Outline}

5.1. Warm-up (motivating)

5.2. Task-Based Thematic Instruction (enabling)

\subsubsection{Sub-Conversation}

1) Parallel Dialogue

2) Tension

5.2.2. Stream of consciousness

5.3. Conclusion (enabling)

5.4. Formative Assessment (assessing)

5.5. Further Literary Critical Practice (assessing)

"POA: production-oriented approach" (Wen, 2015: p. 547)

Teaching objective: guide the Ss to analyze the modernist narrative style of Katherine Mansfield, enable them to understand the importance of tension in promoting the plot, and to realize the significance of sub-conversation in revealing the inner world of the characters.

Character building aim: invite the Ss to read literature about love foreign and domestic and discuss the significance of love so as to lead them to form correct view on love.

Teaching strategy: permeation of humanism, comparative study of oriental and occidental cultures, intercultural communication practice and cultivation of critical thinking.

Key point: make an analysis of the narrative characteristics of Katherine Mansfield

Difficult point: interpret the semantic difference between open conversation and sub-conversation

\subsection{Warm-Up}

Introduce Ss to the topic of A Dill Pickle by discussing some quotations about love both from English writers and Chinese writers.

(immersion)

"Tell me and I forget. Teach me and I remember. Involve me and I learn."

-Benjamin Franklin 
(Constructivism: study by experience and involvement)

Activating prior knowledge:

1) I would rather share one lifetime with you than face all the ages of this world alone.

—Lord of the Rings: Fellowship of the Ring

(Significance of love: to exorcise monotony and loneliness)

2) Love's fire heats water, water cools not love.

-Shakespeare, Sonnet 154

(Significance of love: to evoke passion)

3) Till a' the seas gang dry, my dear,

And the rocks melt wi' the sun;

I will luve thee still, my dear,

While the sands o' life shall run.

—Robert Burns, A Red, Red Rose

(Significance of love: love is eternal.)

4) How many loved your moments of glad grace,

And loved your beauty with love false or true,

But one man loved the pilgrim soul in you,

And loved the sorrows of your changing face;

—William Butler Yeats

(Significance of love: love is not so much physical as spiritual.)

5) Our roots, entwined underground,

Our leaves, touching in the clouds.

Seemingly always apart,

But also forever interdependent.

-Johanna Yueh (trans), To the Oak Tree

(Significance of love: love is based on equality and personal independence.)

6) And if the golden sun,

Should cease to shine its light,

Just one smile from you,

Would make my whole world bright.

-Lord Byron, If You Were a Teardrop in My Eye

(Significance of love: Love is to inspire and appreciate each other.)

7) "Sometimes it lasts in love, but sometimes it hurts instead."

-Adele, Someone Like You

(Significance of love: Love is bittersweet, both fulfilling and frustrating.) What is the significance of love for human beings?

(generalization of the previous quotations)

Interacting with others:

Task 1: What happened to the love in the short story? (for male students)

(scaffolding) (Aim: prediction about the contents/top-down) 
1) to break up with each other,

2) to be disillusioned with love,

3) to meet her old flame,

4) to reminisce about their shared interest,

5) to renew their romantic relationship.

Try to answer the question by analyzing the open conversation and sub-conversation of the short story.

Task 2: What is the narrative style of Katherine Mansfield? (for female students)

(scaffolding: point of view, narrative voice, focus, emphasis and discourse and subject matter. Aim: analysis of the form/top-down)

\subsection{Task-Based Thematic Instruction}

Teaching strategy: foster the spirit of scientific inquiry and strengthen the critical thinking ability of the Ss through task-based thematic instruction.

Making use of academic content:

\subsubsection{Sub-Conversation}

Rely on context for its meaning. "The most valuable aesthetic functions of sub-conversation exist in building the semantic difference between conversation and sub-conversation to foreground the suggestion of the inner world of characters, and in inviting the readers to bear the psycho-tension on the basis of imagination to reveal the unconscious elements" (Huang, 2001: p. 6).

1) Parallel dialogues: one explicit, seems discursive or wandering, the other implicit suggestive and concentrating. (structure)

2) Building tension emerging and submerging, explicit and implicit, outer or inner, to depict the subtle and intense mental state of the characters. (function)

3) Evoking the reader's imagination to bridge the gap between the underlying meaning and what is represented. (means)

1) Parallel dialogues: comparative study of open conversation and sub-conversation (Organizing information)

Cultivating critical thinking (Table 3):

Bottom-up: Why does the man mention music and travelling in the first place?

a) in the imagination of readers: recalling their shared interest to fan the ember of their former love into fire.

b) in reality: no intention to pick up their romantic relationship (P52, P64).

Bottom-up: What is the symbolic meaning of "strange beast" in P31?

a) Vera's long-cherished wish to travel to all those distant and mysterious places.

b) her buried affections for the man since he is a man not without attraction.

Top-down: Why does the author use "a dill pickle" as the title of this short story?

a) It symbolizes their bittersweet love that tastes like a dill pickle, sweet, sour, spicy and over time bitter. 
Table 3. Parallel dialogues.

\begin{tabular}{|c|c|c|}
\hline Parallel dialogues & $\begin{array}{l}\text { Open conversation: Approach } \\
\text { each other through reminiscing } \\
\text { about happy old days }\end{array}$ & $\begin{array}{l}\text { Sub-conversation: Detach } \\
\text { herself from the man with } \\
\text { self-determination }\end{array}$ \\
\hline $\begin{array}{l}\text { 1) the initial dialogue } \\
\text { about her "changed" or } \\
\text { "not changed" (P3-P13) }\end{array}$ & $\begin{array}{l}\text { changed: her appearance, health, } \\
\text { and circumstance (P2, P6) }\end{array}$ & $\begin{array}{l}\text { unchanged: her view of the } \\
\text { character of the man, his trick } \\
\text { of interrupting her (P9, P12) }\end{array}$ \\
\hline $\begin{array}{l}\text { 2) the dialogue about } \\
\text { their first afternoon at } \\
\text { Kew Gardens (P13-P15) }\end{array}$ & $\begin{array}{l}\text { enjoyment for the man, } \\
\text { "fine and warm". (P13) }\end{array}$ & $\begin{array}{l}\text { suffering for Vera, "absurd } \\
\text { and indecent". (P14) }\end{array}$ \\
\hline $\begin{array}{l}\text { 3) the dialogue about } \\
\text { his travelling in Russia } \\
\text { (P22-P46) }\end{array}$ & $\begin{array}{l}\text { 1) the man: far better looking, } \\
\text { confident, and successful. } \\
\text { (P22, P25, P30) } \\
\text { 2) the man: indifferent to the } \\
\text { exacerbating circumstance of } \\
\text { Vera (P40) }\end{array}$ & $\begin{array}{l}\text { 1) Vera: deteriorating, and envious } \\
\text { of the man's travelling experiences. } \\
\text { (P31, P36-39) } \\
\text { 2) Vera: sensitive to music, and } \\
\text { travelling (seems to empathize } \\
\text { with him) (P33, P43) }\end{array}$ \\
\hline $\begin{array}{l}\text { 4) dialogue about the } \\
\text { man's childhood and } \\
\text { their breakup (P47-58) }\end{array}$ & $\begin{array}{l}\text { 1) The man has practically } \\
\text { forgotten everything about their } \\
\text { past love. (P49, P52 L2-3) } \\
\text { 2) The man has pulled through } \\
\text { their bitter breakup. (P52) } \\
\text { 3) The man's love is superficial } \\
\text { and illusionary. (P57) }\end{array}$ & $\begin{array}{l}\text { 1) Vera has always cherished } \\
\text { that memory. (P48) } \\
\text { 2) Vera has never truly recovered } \\
\text { from the painful experience. (P53-54) } \\
\text { 3) Vera is pleased with his words } \\
\text { but not moved. (P58 purr) }\end{array}$ \\
\hline $\begin{array}{l}5 \text { ) the final dialogue } \\
\text { about the causes to } \\
\text { the failure of their } \\
\text { love (P59-64) }\end{array}$ & $\begin{array}{l}\text { 1) The man makes it clear that } \\
\text { he doesn't intend to renew their } \\
\text { past love. (P64 L1) } \\
\text { 2) The man is an egoist and } \\
\text { hasn't a corner in his heart for } \\
\text { anybody else. (P64 L3-4) }\end{array}$ & $\begin{array}{l}\text { 1) Vera wavers for a moment } \\
\text { on whether to give it another } \\
\text { chance. (P60) } \\
\text { 2) Vera is lonely but not self-engrossed; } \\
\text { she is physically weak but spiritually } \\
\text { alive; she doesn't talk much but she is } \\
\text { courageous enough to make her own } \\
\text { choice in love. (P53-54, P65) }\end{array}$ \\
\hline
\end{tabular}

b) It may symbolize Vera's sensibility to the man's travelling experiences (P43).

\section{Bottom-up: Why does she suddenly decide to leave?}

a) The man has ceased to cherish their romantic memory (P52 L1-3).

"seemed such ages ago, ...take such a leap to get back to that time"

b) She is hurt by the man's trivializing their past love (P52 L5-6, P54).

Task Performance 1: Ask each of the two groups of male students to summarize what happened to the love in the story before their chance meeting and after it.

\section{2) Tension}

Tension is the conflict in a situation between characters, or the actual opposition of characters; in Othello, for instance, the conflicts between Iago, Roderigo, Othello and Desdemona. There may also be internal conflict, as in Hamlet's predicament of wishing to avenge his father and yet not knowing when and how to 
do it. Conflict may also occur between a character and society or environment. An example is Jude's efforts in Thomas Hardy's Jude the Obscure to overcome the social obstacles which keep him from university (Cuddon, 1998: p. 175).

Tension between open conversation and sub-conversation:

1) inconsistency in behavior (P55/64)

2) irrelevance of words $(\mathrm{P} 25,57)$

3) contradiction in ideas (P13/14)

4) conflict between opposing desires or values in temperament (P60)

(interior monologue: conformity VS self-determination)

\subsubsection{Stream of Consciousness}

Stream of consciousness refers to the continuous flow of sense-perceptions, thoughts, feelings, and memories in the human mind; The modernist technique was pioneered by James Joyce in Ulysses (1922), and further developed by Virginia Woolf in Mrs Dalloway (1925) and William Faulkner in The Sound and the Fury (1928).

1) The stream of consciousness is the subject-matter while interior monologue is the technique for presenting it directly;

2) Involving apparent intervention of a selecting narrator, violating the norms of grammar, syntax, and logic (Baldick, 2001: p. 244).

P16: The memory of the first afternoon they spent together, and she wished she could have some warm sunshine at that moment.

P33: Reminiscing about the happy old days when they shared music.

P43: It shows that although it was the man who was reminiscing, it was Vera who was more emotionally involved. Once again we are impressed by Vera's sensitivity to beauty.

P60: Revealing Vera wavers for a moment on whether to give it another chance.

Task Performance 2: Invite the leaders of 4 teams of the female students to report to the class the narrative features of Katherine Mansfield from the perspective of narrative discourse, point of view, narrative focus and emphasis.

\subsection{Conclusion}

\section{Cultivating critical thinking:}

What are the narrative features of Katherine Mansfield?

\section{1) The focus of narration}

"A Dill Pickle is published in the New Age on October 4, 1917" (Norburn, 2002: p. 44). This short story is about male-female relationships as seen through women's eyes written by Katherine Mansfield, who enjoys the reputation of being an English Chekhov. The story really focuses on Vera, and readers are supposed to reconstruct the whole story from her perspective. Although the man does most of the talking, the feminist author has not even given the petty, mean man a name.

2) Narrative voice and subject matter 
"Mansfield's third-person narrators sometimes have a 'voice' that erases the boundary between the written and the spoken word as if discourse always meant a form of individuation through voice: 'And then, after six years she saw him again"” (Wilson, 2011: p. 92).

"One of the most noticeably dramatic of Mansfield's techniques is the use of the 'slices of life', where the action occupies merely a brief instant of time. For René Godenne, 'the key stone of Mansfield's short story is really the moment'. These 'moments' can be divided into two distinct types: the 'habitual' and the 'unique'; the former reveals a typical moment in a particular life/lives (e.g. The Man without a Temperament), whereas the latter describes a unique event in a given life which may never be repeated (e.g. Bliss, A Dill Pickle)" (Kimber, 2015: p. 14).

\section{3) Symbolic use of objects and incidents and accuracy of detail}

The peculiar features of her stories are the symbolic use of objects and incidents and accuracy of detail. "She raised her veil and unbuttoned her high fur collar". Symbolizes she is open for communication with the man. "She had buttoned her collar again and drawn down her veil". Symbolizes once again she is determined to leave the man.

\section{4) Emphasis on atmosphere and psychological portrayal}

She is not usually concerned so much with the development of the plot as with building atmosphere. Describing her characters, she doesn't so much stress what they do, but what they are and what they feel. She is more interested in their inner life, which is naturally revealed through sub-conversation and their behavior.

\subsection{Formative Assessment}

Teaching strategy: task-based formative assessment advocating team spirit, kindness independence and harmony.

Divide the Ss into two teams and ask them to complete each of the following tasks to further their understanding of love.

\section{Interacting with others:}

\section{Team A}

1) Consult your parents about what is love.

2) Write a report on your inquiry and share it with the class.

\section{Team B}

1) Interview a foreign couple or some overseas students about what is love.

2) Share your main findings with the class.

\subsection{Further Literary Critical Practice}

Please make a critical reading of other stories of Katherine Mansfield from the following perspectives:

(Acquaint the Ss with critical perspective and lead the Ss to boundless knowledge.)

1) Sub-Conversation; 
2) Female as the focus of narration;

3) Narrative voice that erases the boundary between written and spoken word;

4) The use of the "slices of life";

5) The symbolic use of objects and incidents and accuracy of detail;

6) Emphasis on atmosphere and psychological portrayal.

\section{Works for your reference:}
1) A Bad Idea
2) An Ideal Family
3) Bliss
4) Honeymoon
5) Miss Brill
6) Six Years After
7) The Escape
8) The Canary
9) The Fly
10) The Man without a Temperament

\section{Conclusion and Assessment}

\section{Outline}

6.1. Role Play-Love Counseling (motivating)

6.2. Topic Report (enabling)

6.3. Quiz (assessing)

6.3.1. True or False Questions

6.3.2. Multiple-choice Questions

6.4. Conclusion

"POA: production-oriented approach" (Wen, 2015: p. 547)

Teaching objective: strengthen students' memory of the new knowledge that they have learned previously; train their ability to analyze and solve problems with target language; organize students to analyze the connotation of love in depth, and guide students to establish a correct view of love.

Character building aim: in the concluding part, the teacher will put emphasis on building students' self-confidence and self-esteem characters, cultivating students' optimistic and strong spirits, establishing students' harmonious and friendly love concepts.

Teaching strategy: interactive teaching method, permeation of humanism, heuristic method of teaching.

Key point: encourage students to make an analysis of the problems in the relationship between the hero and the heroine.

Difficult point: guide students to establish a correct view of love through love counseling and topic report.

\subsection{Role Play-Love Counseling}

\section{Interacting with others}

Suppose that you are a relationship counselor, please give advice to the former couple on what goes wrong in their relationship and how they can make up, if possible.

\subsection{Topic Report}

\section{Cultivating critical thinking}

Write a report on your attitude toward love and share it with the class. 


\subsection{Quiz}

\subsubsection{True or False Questions}

1) The man pays much attention to Vera's plight and is willing to help Vera.

2) Vera and the man meet after six years and share their memories of the past.

3) During six years of separation, the man travelled overseas with his new girlfriend.

4) Vera is lonely, and she is also egotistic like the man.

\subsubsection{Multiple-Choice Questions}

Key: 1) A, 2) B, 3) C, 4) D

1) The short story is written in the style of stream of consciousness with emphasis on the expression of.
A. thoughts and feelings
C. natural scenery
B. plots
D. conversations

2) Vera and the man meet after six years and share their of the past.
A. love
C. hatred
B. memories
D. sadness

3) "The strange beast" in paragraph 31 refers to Vera's to travel to distant and mysterious places.
A. hesitation
C. wish
B. rejection
D. courage

4) One major theme of the story is that memories are sometimes altered by time and
A. illness
C. loneliness
B. separation
D. emotion

\subsection{Conclusion}

The concluding part is also made up of three steps under the guidance of POA. In the first step, the teacher will organize a "Love Counseling" activity to arouse students' interest and motivation. According to constructivism, learners do not accept knowledge passively, but form cognition by constructing the meaning of knowledge actively. Constructivism requires teachers to present opportunities for real world contact and real use of language. Based on their original cognition and experience, students re-appreciate and encode new information, thus forming their own understanding and perfecting their knowledge structures under teachers' support and assistance. In this case, students are encouraged to be a relationship counselor, giving advice to the former couple on what goes wrong in their relationship and how they can make up. When students encounter difficulties in communication, the teacher will provide them with appropriate direction. By building this specific situation and giving students effective guidance and feedbacks, the teacher can cultivate students' innovative spirit and cooperative 
consciousness as well as training their ability to analyze and solve problems with target language. In the meantime, the teacher enables students to observe the world and ponder the life on the basis of their own cognitive structures, helps them to analyze the connotation and meaning of love in depth, and hence enhances the education of love concept. After that, students are asked to write a report on their attitude toward love and share it with the class for the consideration of enabling. It is acknowledged that peer scaffolding is also significant for individual cognitive development and language acquisition. Hence, before writing, students are encouraged to brainstorm ideas for writing, since their thoughts can be inspired by each other's sparkling thoughts. Accordingly, the teacher will provide students with useful and positive feedbacks after their demonstrations, including the establishment of a healthy view on love and the improvement of writing deficiencies. Finally, a quiz concerning the content of the reading material will be given to the students. Students are asked to make "True or False" selections and take a multiple-choice test. This quiz is an assessment of students' knowledge of the text, involving some key elements covered in the text, like writing style, plot, characterization, theme, and so on. After completing the quiz, students are asked to make peer corrections, while sharing answers, explaining reasons, and correcting faults. The Mosaic model in teaching English intensive reading is built on the basis of constructivist theory of learning and teaching. It is proved feasible in the paper to teach intensive English with the Mosaic model, and the model can also be applied to the teaching of other subjects in TESOL class, like extensive reading, writing, translation practice and public speaking, to enhance the comprehensive English ability of the Ss.

\section{Fund}

This paper is for partial fulfillment of the research and practice project of Online and Offline Integrated First-class Course in Nanjing Normal University Zhongbei College, with the Project Number: 2020yjkc002.

\section{Conflicts of Interest}

The authors declare no conflicts of interest regarding the publication of this paper.

\section{References}

Baldick, C. (2001). The Concise Oxford Dictionary of Literary Terms (p. 244). New York: Oxford University Press.

Cuddon, J. A. (1998). The Penguin Dictionary of Literary Terms and Literary Theory (p. 175). London: Penguin Books.

Hitchcock, D. (2018). Critical Thinking. In E. N. Zalta (Ed.), The Stanford Encyclopedia of Philosophy.

https://plato.stanford.edu/archives/fall2018/entries/critical-thinking

Hornby, A. S. (2004). Advanced Learner's English-Chinese Dictionary (6th ed.). Beijing: The Commercial Press. 
Huang, X. Y. (2001). The Context, Implication and Psychological Tension of Sub-Conversation. Journal of South China Normal University (Social Science Edition), No. 6, 51-55.

Jones, M. G., \& Brader-Araje, L. (2002). The Impact of Constructivism on Education: Language, Discourse, and Meaning. American Communication Journal, 5, 89.

Kimber, G. (2015). Katherine Mansfield and the Art of the Short Story (pp. 4-6-14). New York: Palgrave Macmillan. https://doi.org/10.1057/9781137483881_4

Lo, J. J., Yeh, S. W., \& Sung, C. S. (2010). A Scaffolding Support System for English Essay Reading. In Advances in Web-Based Learning (pp. 180-189). Lecture Notes in Computer Science, Vol. 6483, Berlin: Springer.

https://doi.org/10.1007/978-3-642-17407-0_19

Murphy, R. (2019). English Grammar in Use (5th ed., p. 80) Cambridge: Cambridge University Press.

Norburn, R. (2002). A Katherine Mansfield Chronology (p. 44). New York: Palgrave Macmillan.

Pande, M., \& Vijayakumar Bharathi, S. (2020). Theoretical Foundations of Design Thinking-A Constructivism Learning Approach to Design Thinking. Thinking Skills and Creativity, 36, Article ID: 100637. https://doi.org/10.1016/j.tsc.2020.100637

Piaget, J. (1967). Biology and Knowledge (p. 145). Paris: Gallimard.

Royce, A. W. (1989). Developing Reading Versatility (p. 185). New York: Holt, Rinehart and Winston, Inc.

Vygotsky (1978). Mind in Society: The Development of Higher Psychological Processes (p. 7). Cambridge, MA: Harvard University Press.

Wen, Q. F. (2015). Developing a Theoretical System of Production-Oriented Approach in Language Teaching. Foreign Language Teaching and Research, 4, 547-558.

Wen, Q. F. (2018). Production-Oriented Approach in Chinese as a Second Language. Chinese Teaching in the World, 3, 387-400.

Williams, G. (2014). Harkness Learning: Principles of a Radical American Pedagogy. Journal of Pedagogic Development, 4, 58-67.

Wilson, J. (2011). Katherine Mansfield and Literary Modernism (p. 92). London: Continuum.

Yang, L. M. (2011). Contemporary College English 3 (Student's Book). Beijing: Foreign Language Teaching and Research Press. 